\title{
Editorial
}

Matthias Dütsch, Ralf Himmelreicher, Christian Pfeifer* and Conny Wunsch

\section{Editorial: Effects of the Introduction of the Statutory Minimum Wage in Germany}

\author{
https://doi.org/10.1515/jbnst-2019-0059
}

On January 1, 2015, Germany introduced a new national minimum wage of $€ 8.50$ (gross) per hour. It was increased to €8.84 on January 1, 2017, and to €9.19 on January 1, 2019. At its introduction, the new minimum wage was binding for almost 37 million dependent employees. Because of the number of people impacted, this wide-ranging measure has constituted the most important labour market reform in Germany since the Agenda 2010 programme in the early 2000s.

Before its introduction, the national minimum wage was often considered as a "grand social experiment". Accordingly, discussions of potential effects have been contentious, and scientific forecasts have differed considerably. Supporters of a statutory minimum wage have focused on fairness issues and stressed the positive impacts on wages and consumption, citing also the anticipated reduction in employees' dependence on social transfers (Bosch 2007; Schulten/Horn 2014; Kalina/Weinkopf 2014). In contrast, critics of the minimum wage have emphasized its potential negative impact on employment and have predicted a loss of 500,000 to nearly a million jobs (Arni et al. 2014; Müller/Steiner 2011; Knabe et al. 2014). In a special context, concerns were raised that urban poverty would increase (Buettner/Ebertz 2009).

A long tradition of minimum wage research exists in the United States. Since the early 1990s, a large number of studies have examined causal effects of a minimum wage based on regional variations. While work in the research tradition of Card and Krueger (Card 1992; Card/Krueger 1994, 1995) found little or no impact on employment resulting from a minimum wage, studies in the research

\footnotetext{
*Corresponding author: Christian Pfeifer, Institute of Economics, Leuphana Universitat Luneburg, Luneburg 21335, Germany, E-mail: pfeifer@leuphana.de

Matthias Dütsch: E-mail: matthias.duetsch@geschaeftsstelle-mindestlohn.de, Ralf Himmelreicher: E-mail: ralf.himmelreicher@geschaeftsstelle-mindestlohn.de, Geschäfts- und Informationsstelle für den Mindestlohn Mindestlohnkommission c/o Bundesanstalt für Arbeitsschutz und Arbeitsmedizin, Nöldnerstr. 40-42, Berlin 10317, Germany Conny Wunsch, University of Basel, Basel, Switzerland, E-mail: conny.wunsch@unibas.ch
} 
tradition of Neumark and Wascher (Neumark/ Wascher 1992, 2008; Neumark et al. 2014) identified weak to significant negative effects of minimum wages on employment. In the United Kingdom, results mainly indicate no significant employment effects (Dickens et al. 1999; Dolton et al. 2015, 2012, 2010; Manning 2013; Metcalf 2008; Stewart 2004). International empirical evidence on working hours and work intensity is also mixed (Belman/Wolfson 2014; Low Pay Commission 2016; Neumark/Wascher 2008; Schmitt 2015); however, prices for goods and services were found to increase in specific sectors that employ a higher share of employees who are covered by the minimum wage (Belman/ Wolfson 2014; Lemos 2008), while in the United Kingdom the minimum wage reduced firm profitability (Draca et al. 2011).

Actually, the German national minimum wage was initially set at a relatively high level in comparison to other countries that have introduced a national minimum wage. Measured by the Kaitz index, the new German minimum amounted to $48 \%$ of the German median wage in 2015 , on a par with the United Kingdom (where the Kaitz index for that year was 49\%) and the Netherlands (where it was 46\%). The highest index (62\%) was in France, and the lowest were in Spain, where it was 37\%, and the United States, where it was $36 \%$ (OECD [Organisation for Economic Co-operation and Development] 2017). However, when the United Kingdom introduced its minimum wage in 1999, the Kaitz index was only $42 \%$. The share of employees affected by the new minimum wage in Germany was also high: around 4 million jobs had previously paid below €8.50 gross per hour (Mindestlohnkommission 2016). In the United Kingdom, when the minimum wage was introduced the coverage was $5.3 \%$ (Low Pay Commission 2001). Furthermore, the bite of the minimum wage differed considerably across German regions, reaching Kaitz indices of more than $60 \%$ in the eastern regions of Germany (Mindestlohnkommission 2016).

Against this backdrop, this special issue titled Effects of the Introduction of the Statutory Minimum Wage in Germany provides a comprehensive look at the short-term effects of the introduction of the national minimum wage; it comprises seven articles which empirically evaluate the effects of the national minimum wage on a broad range of topics.

In their article "Characteristics Contributing to Low- and Minimum-Wage Labour in Germany”, Matthias Dütsch and Ralf Himmelreicher examine the correlation between characteristics of individuals, companies, and industries involved in low-wage and minimum-wage labour in Germany. They find that the influence of individual characteristics on wage levels is often overstated: several determinants related to individuals appear to suggest a high low-wage incidence, but they in fact lose their explanatory power once controls are added for factors relating to the companies or industries that employ these individuals. 
Patrick Burauel, Marco Caliendo, Markus M. Grabka, Cosima Obst, Malte Preuss, Carsten Schröder, and Cortnie Shupe, in their article "The Impact of the German Minimum Wage on Individual Wages and Monthly Earnings”, evaluate the impact of the minimum wage on hourly wages and monthly earnings of workers targeted by the reform. Their results indicate that the minimum wage introduction can account for hourly wage growth on the order of roughly $6.5 \%$, or $€ 0.45$ per hour, and an increase in monthly earnings of $6.6 \%$, or $€ 53$ per month. Furthermore, the article documents widespread noncompliance with the mandated wage floor of $€ 8.50$ per hour.

Marco Caliendo, Markus M. Grabka, Cosima Obst, Malte Preuss, and Carsten Schröder, in their article "The Impact of the Minimum Wage on Working Hours", analyse the impact of the minimum wage on employees' hours worked. The authors identify a significant and robust reduction in contractual working hours among employees who are in regular employment and who earned less than the minimum wage before the introduction. The effect in 2015 amounts to a reduction of $5 \%$, or 1.7 hours of average weekly working time. The effect on actual hours worked is smaller and estimated less precisely than the reduction in contractual working hours.

Martin Friedrich, in his article "Using Occupations to Evaluate the Employment Effects of the German Minimum Wage", investigates the short to medium run employment effects of the minimum wage. The effect of the policy is identified by using variation in the bite of the minimum wage across occupations using a difference-in-differences estimator. His analysis reveals that the reform only had a small impact on employment and highlights the importance of regional effect heterogeneity. In East Germany, marginal employment decreased by about 18,000 jobs in the short run and 52,000 jobs in the medium run, respectively, due to the minimum wage. In West Germany, no negative employment effects are detectable, but regular employment increased temporarily because of the reform.

Holger Bonin, Ingo E. Isphording, Annabelle Krause-Pilatus, Andreas Lichter, Nico Pestel, and Ulf Rinne, in their article "The German Statutory Minimum Wage and Its Effects on Regional Employment and Unemployment”, study the effects of the minimum wage on the level of regional labour markets. Using as their point of comparison regional variations in terms of exposure to the new wage floor, the authors fail to detect any statistically significant impact from the introduction of the minimum wage on regular employment subject to social insurance, but they do find a statistically significant negative effect on marginal employment. However, this reduction in marginal employment is not accompanied by a proportional increase in overall unemployment.

Mario Bossler, Nicole Gürtzgen, Benjamin Lochner, Ute Betzl, and Lisa Feist, in their article "The German Minimum Wage: Effects on Productivity, Profitability, 
and Investments", use data on German establishments. They show that in companies affected by the minimum wage, personnel costs have increased significantly while the net sales of intermediates have decreased. Their results do not point to effects on establishment-level productivity, capital investments, or investments in human capital.

Helge Braun, Roland Döhrn, Michael Krause, Martin Micheli, and Torsten Schmidt, in their article "Macroeconomic Long-Run Effects of the German Minimum Wage when Labor Markets are Frictional”, employ a simple neoclassical model where wages equal workers' marginal product. The authors extend this model to a two-sector economy and introduce search and matching frictions to gain quantitative insights into different mechanisms and channels through which minimum wages affect outcomes in the long run. Their framework leads them to conclude that the minimum wage has a strong negative effect on employment. In cases in which different sectors experience different impacts from the minimum wage, relative price changes of labour play an important quantitative role.

This special issue of the Journal of Economics and Statistics provides a comprehensive overview of the effects of the introduction of the statutory minimum wage in Germany. The seven empirical articles deal with interactions between the minimum wage and micro- and macro-oriented aspects of the labour market, such as wages, working hours, employment, productivity, and investments. We hope that this volume will help to stimulate broad and far-ranging discussions about the economic and policy implications of introducing a minimum wage and inspire readers to start their own research projects on minimum wages. Various approaches to investigate minimum wage effects and to operationalise hourly wages are described in Baumann et al. (2018) and Dütsch et al. (2019).

\section{References}

Arni, P., W. Eichhorst, N. Pestel, A. Spermann, K.F. Zimmermann (2014), Der gesetzliche Mindestlohn in Deutschland: Einsichten und Handlungsempfehlungen aus der Evaluationsforschung. Schmollers Jahrbuch 134 (2): 149-182.

Baumann, A., O. Bruttel, M. Dütsch, R. Himmelreicher, C. Ohlert (2018), Methoden zur Evaluation des gesetzlichen Mindestlohns in Deutschland. Zeitschrift für Evaluation 17 (1): 81-107.

Belman, D., P.J. Wolfson (2014), What Does the Minimum Wage Do? W. E. Upjohn Institute for Employment Research/Kalamazoo.

Bosch, G. (2007), Mindestlohn in Deutschland notwendig - Kein Gegensatz zwischen sozialer Gerechtigkeit und Beschäftigung. Zeitschrift für ArbeitsmarktForschung 40 (4): 421-430.

Buettner, T., A. Ebertz (2009), Spatial Implications of Minimum Wages. Journal of Economics and Statistics 229 (2+3): 292-312. 
Card, D. (1992), Do Minimum Wages Reduce Employment? A Case Study of California, 1987-89. Industrial and Labor Relations Review 46 (1): 38-54.

Card, D., A.B. Krueger (1994), Minimum Wages and Employment: A Case Study of the Fast-food Industry in New Jersey and Pennsylvania. American Economic Review 84 (4): 772-793.

Card, D., A.B. Krueger (1995), Myth and Measurement. The New Economics of the Minimum Wage. Princeton University Press/Princeton.

Dickens, R., S. Machin, A. Manning (1999), The Effects of Minimum Wages in Employment: Theory and Evidence from Britain. Journal of Labor Economics 17 (1): 1-22.

Dolton, P., C.R. Bondibene, M. Stops (2015), Identifying the Employment Effect of Invoking and Changing the Minimum Wage: A Spatial Analysis of the UK. Labour Economics 37: 54-76.

Dolton, P., C.R. Bondibene, J. Wadsworth (2010), The UK National Minimum Wage in Retrospect. Fiscal Studies 31 (4): 509-534.

Dolton, P., C.R. Bondibene, J. Wadsworth (2012), Employment, Inequality and the UK National Minimum Wage over the Medium-term. Oxford Bulletin of Economics and Statistics 74 (1): 78-106.

Draca, M., S. Machin, J. Van Reenen (2011), Minimum Wages and Firm Profitability. American Economic Journal: Applied Economics 3 (1): 129-151.

Dütsch, M., R. Himmelreicher, C. Ohlert (2019), Calculating Gross Hourly Wages - the (Structure of) Earnings Survey and the German Socio-Economic Panel in Comparison. Journal of Economics and Statistics 239 (2): 243-276.

Kalina, T., C. Weinkopf (2014), Niedriglohnbeschäftigung 2012 und was ein gesetzlicher Mindestlohn von 8,50 € verändern könnte, IAQ-Report 2014-02, Institut Arbeit und Qualifikation, Duisburg.

Knabe, A., R. Schöb, M. Thum (2014), Der flächendeckende Mindestlohn. Perspektiven der Wirtschaftspolitik 15 (2): 133-157.

Lemos, S. (2008), A Survey of the Effects of the Minimum Wage on Prices. Journal of Economic Surveys 22 (1): 187-212.

Low Pay Commission (2001), The National Minimum Wage. Making a Difference. Third Report of the Low Pay Commission. Volume One, London.

Low Pay Commission (2016), National Minimum Wage. Low Pay Commission Report Autumn 2016, London.

Manning, A. (2013), Minimum Wages: A View from the UK. Perspektiven der Wirtschaftspolitik 14 (1-2): 57-66.

Metcalf, D. (2008), Why Has the British National Minimum Wage Had Little or No Impact on Employment? Journal of Industrial Relations 50 (3): 489-512.

Mindestlohnkommission (2016), Erster Bericht zu den Auswirkungen des gesetzlichen Mindestlohns. Bericht der Mindestlohnkommission an die Bundesregierung nach $§ 9$ Abs. 4 Mindestlohngesetz, Berlin.

Müller, K.-U., V. Steiner (2011), Beschäftigungswirkungen von Lohnsubventionen und Mindestlöhnen - Zur Reform des Niedriglohnsektors. Zeitschrift für ArbeitsmarktForschung 2011 (44): 181-195.

Neumark, D., I.J.M. Salas, W. Wascher (2014), Revisiting the Minimum Wage-employment Debate: Throwing Out the Baby with the Bathwater? Industrial and Labor Relations Review 67 (3): 608-648.

Neumark, D., W. Wascher (1992), Employment Effects of Minimum and Subminimum Wages: Panel Data on State Minimum Wage Laws. Industrial and Labor Relations Review 46 (1): 55-81. 
Neumark, D., W. Wascher (2008), Minimum Wages. MIT Press/Cambrigde, MA.

OECD [Organisation for Economic Co-operation and Development] (2017), Minimum Wage Database. Abrufbar unter: https://stats.oecd.org/Index.aspx?DataSetCode=MIN2AVE [Abfragedatum: 12.06.2018].

Schmitt, J. (2015), Explaining the Small Employment Effects of the Minimum Wage in the United States. Industrial Relations 54 (4): 547-581.

Schulten, T., G. Horn (2014), Das Mindestlohngesetz - ein wichtiges Instrument zur Stabilisierung der Lohnentwicklung. Wirtschaftsdienst 94 (6): 395-398.

Stewart, M.B. (2004), The Impact of the Introduction of the U.K. Minimum Wage on the Employment Probabilities of Low-wage Workers. Journal of the European Economic Association 2 (1): 67-97.

Article note: This article is part of the special issue "Effects of the New Statutory Minimum Wage in Germany" published in the Journal of Economics and Statistics. Access to further articles of this special issue can be obtained at www.degruyter.com/journals/jbnst. 